University of New Hampshire

University of New Hampshire Scholars' Repository

Law Faculty Scholarship

University of New Hampshire - Franklin Pierce

School of Law

3-1-1995

\title{
The Tenth Circuit: Playing by the Rules
}

Keith M. Harrison

University of New Hampshire School of Law

Follow this and additional works at: https://scholars.unh.edu/law_facpub

Part of the Criminal Procedure Commons

\section{Recommended Citation}

Keith M. Harrison, "The Tenth Circuit: Playing by the Rules," 7 Fed. Sent'g. Rep. 258 (1994-1995).

This Article is brought to you for free and open access by the University of New Hampshire - Franklin Pierce School of Law at University of New Hampshire Scholars' Repository. It has been accepted for inclusion in Law Faculty Scholarship by an authorized administrator of University of New Hampshire Scholars' Repository. For more information, please contact sue.zago@law.unh.edu. 


\section{THE TENTH CIRCUIT: PLAYING BY THE RULES}

\author{
Keith M. Harrison*
}

In 1994, the Tenth Circuit published more than four dozen opinions construing the guidelines and joined the majority of circuits in adopting the "OneBook" rule. The Court continued to refrain from interfering with the exercise of discretion by district judges, but made clear that it does not give district courts carte blanche.

Four issues in decisions covered in this review are the retroactive application of amendments to the guidelines; the standards used in characterizing a defendant as a major or minor player for purposes of increasing or decreasing the sentence; the impact of post-arrest efforts at rehabilitation on sentencing-at least in drug cases; and the elements of obstruction of justice for purposes of increasing a sentence.

\section{EX POST FACTO ARGUMENTS AND THE "ONE BOOK" RULE}

In several cases, the Circuit addressed arguments that defendants had been unconstitutionally punished by the application of amendments which became effective after the commission of their crimes. The general rule followed by the court is that no guideline amendment can cause the defendant to be punished more severely than he or she would have been under the version of the guidelines in effect at the time of the crime.

When a defendant urges that ex post facto principles require the use of prior guideline provision, the question arises as to whether the entire prior version of the guidelines or only the specific provision should be applied. In United States $v$. Nelson, the Tenth Circuit announced that it would join the First, Second, Third, Seventh and Eighth Circuits, and adopt the One-Book rule. ${ }^{1}$ Thus a defendant, who complained that application of the 1992 guidelines unconstitutionally raised his offense level by seven instead of six as required under the 1988 guidelines, could not simultaneously ask the court to use the more generous 1992 guidelines in determining how many levels to decrease his offense. The defendant will be sentenced pursuant to one version or "OneBook" of the guidelines.

In another decision concerning the application of ex post facto principles, the court addressed arguments by a defendant who sought a decrease based on her assistance to the government. ${ }^{2}$ Joan Gerber had committed her offenses in March and April 1989, while the 1988 guidelines were in effect allowing an offense level reduction when the defendant provided

* Associate Professor of Law, University of Denver. good faith assistance to the government. The government conceded that during debriefing concerning her money laundering and racketeering activities, Gerber was "open and candid with the information that she did possess' and [made] ... a 'fairly strong effort' to assist" the government. However, the government maintained that her information did not rise to the level of being substantial because it "'was not sufficient for [the government] to move on in any way, shape or form."'

Gerber was sentenced under the 1989 guidelines which, in her case, were less favorable since they allowed only for a reduction in cases involving substantial assistance to the government. Her assistance, however, was characterized as good faith but not substantial. She argued on appeal that application of the later guidelines violated the ex post facto clause of the Constitution. The court ruled that whle the change was substantive, ${ }^{3}$ this section of the guidelines was concerned not with the criminal activity for which the defendant was tried but rather with the assistance the defendant provided to the government. Therefore, the ex post facto clause was not violated as long as the later, less favorable, guidelines were in effect when the defendant started to assist the government, which was the case here.

\section{MAJOR VERSUS MINOR PLAYERS}

Among the most common factors which can affect a change in offense level for crimes involving multiple actors is the significance of the defendant's role in the offense. If a defendant was an organizer, leader, manager or supervisor in the criminal activity, the offense level may be increased by 2 to 4 levels. ${ }^{4}$ In United States $v$. Melendez-Garcia, the court reaffirmed its earlier rulings, and stated that it will not disturb a district court's finding that a defendant is an organizer, leader, manager or supervisor unless that finding was clearly erroneous. 5 To be found a supervisor a defendant in a drug smuggling operation need only do such things as arrange financing, plan and give directions. ${ }^{6}$ In a scheme to illegally export wildlife trophies, the court held in United States $v$. Allemand that although evidence of the defendant's role as a supervisor was "sparse," the district court could have concluded that the defendant "was at least formally responsible for organizing" others involved in the crime because he was their employer.?

To increase the offense level by 3 or 4 levels because the defendant played a major role, the guidelines require a finding that there were five or more participants in the criminal activity. ${ }^{8}$ Taking inspiration from the Third and Fifth Circuits, ${ }^{9}$ the Tenth Circuit held that the other participants need not be guilty of the offense for which the defendant is being sentenced in order for the increase to be made. ${ }^{10}$

The guidelines provide that a defendant who was a minimal or minor participant may have his offense level decreased by 2 to 4 levels." At sentencing a 
defendant bears the burden of establishing by a preponderance of the evidence that she was a minimal or minor participant. ${ }^{12}$ Just as it will not disturb a district court's increase of the offense level, the Tenth Circuit reaffirmed that normally it will affirm a decision not to decrease the level unless clearly erroneous. ${ }^{13}$

\section{DRUG REHABILITATION MAY BE GOOD FOR THE SOUL BUT NOT FOR SENTENCE REDUCTION}

Although the Tenth Circuit is reluctant to secondguess a district judge's exercise of discretion in the application of the guidelines, it apparently has little patience for judges who second-guess the Commission. In two published opinions it refused to allow district judges to award more credit for post-arrest drug rehabilitation efforts than is given by the guidelines. ${ }^{14}$

In United States v. Ziegler ("Ziegler I"), ${ }^{15}$ the Circuit held that drug rehabilitation is not a proper independent ground for departure because the Commission adequately considered drug rehabilitation under $\S 3 \mathrm{E} 1.1$, which provides a two level downward departure for acceptance of responsibility. The district court in Ziegler I had departed below the guideline range by four offense levels because it believed the defendant's remarkable efforts at drug rehabilitation constituted a mitigating circumstance of a kind and to a degree not adequately addressed by the Commission. As such, the district court did not depart under §3E1.1. After concluding that drug rehabilitation is only relevant in the $\S 3 \mathrm{E} 1.1$ context, the Ziegler I court remanded so the district court could consider other potentially mitigating factors.

On remand, the district court again departed by four levels, not under $\S 3 \mathrm{E} 1.1$, but rather under $\$ 5 \mathrm{~K} 2.0$, p.s. This time it concluded that the "mitigating circumstances" of, inter alia, the defendant's drug rehabilitation and the realities of prison overcrowding were not considered by the guidelines. The district court found the defendant's rehabilitative efforts to have so exceeded ordinary expectations that they "fell outside the heartland of the acceptance of responsibility guideline" § 3E1.1, and Ziegler I.

The government appealed for a second time in United States $v$. Ziegler ("Ziegler II"). ${ }^{16}$ The Tenth Circuit reaffirmed its view that drug rehabilitation efforts-even in an extraordinary case-are not sufficient to justify a departure. The court held that the Commission already considered such efforts by allowing for a decrease based on the defendant's acceptance of responsibility and by giving the sentencing court a range within which to sentence. After a sentencing court makes the $\S 3 \mathrm{E} 1.1$ determination, drug "rehabilitation may play no further role in a court's sentencing analysis." 17

The Ziegler II court also rejected the district court's efforts to consider the availability of prison space. The district court relied on 28 U.S.C. $\$ 944(\mathrm{~g})$, which instructs the Commission to consider prison capacity while drafting the guidelines. Noting that $\S 944(\mathrm{~g})$ is directed solely to the Commission, the Circuit held "that using this statutory provision to justify a downward departure from an applicable sentencing range is improper." The court remanded the case for resentencing.

\section{TESTIMONY PLUS CONVICTION DOES NOT EQUAL OBSTRUCTION OF JUSTICE.}

The Tenth Circuit clarified $\S 3 C 1.1$, dealing with obstruction of justice for purposes of enhancing a defendant's sentence. It demonstrated a willingness to enforce obstruction of justice enhancements, but it repeatedly prevented district courts from making such enhancements unless they followed proper procedures.

On one hand, the court did not hesitate to affirm a district court ruling that, because the defendant threatened to harm a witness if she did not lie before a grand jury, he deserved an offense level increase under $\S 3 \mathrm{C} 1.1 .^{18}$

On the other hand, the court reminded judges in three different districts that just because a defendant testifies and the jury convicts does not mean that he has perjured himself and deserves an offense level increase for obstructing justice. ${ }^{19}$ In 1993, the Tenth Circuit had ruled that:

[the] mere fact that a defendant testifies to his or her innocence and is later found guilty by the jury does not automatically warrant a finding of perjury. An automatic finding of untruthfulness, based on the verdict alone, would impinge upon the constitutional right to testify on one's own behalf. ${ }^{20}$

In three 1994 decisions, the court re-instructed the district courts that a guilty verdict which would be inconsistent with the jury's belief in the truthfulness of the defendant's testimony does not, by itself, equal perjury. Consistent with Supreme Court and Tenth Circuit precedent, ${ }^{21}$ the court held that in order to enhance such a defendant's sentence under $\S 3 \mathrm{C} 1.1$, the district court must make specific, independent findings that the defendant committed perjury by intentionally giving untruthful testimony with respect to a material matter. A $\S 3 \mathrm{C} 1.1$ enhancement will not stand if these findings are insufficient. ${ }^{22}$

\section{FOOTNOTES}

136 F.3d 1001, 1004 (10th Cir. 1994) (collecting cases).

2 United States v. Gerber, 24 F.3d 93 (10th Cir. 1994).

${ }^{3}$ The Court also ruled that the ex post facto clause is not implicated if a later version of the guidelines only serves to clarify, and not substantively change, an earlier version. For example, the 1991 amendments to the guidelines which 


\section{TENTH CIRCUIT}

deleted the adjectives "specially protected" in allowing for a one point increase for illegally exporting "wildlife" did not violate the defendants' rights because, historically, violations of this sort had been subject to an increase by another guideline provision. In the 1991 amendments, the Commission only clarified language. United States $v$. Allemand, 34 F.3d 923, 930 (10th Cir. 1994).

4 §3B1.1.

528 F.3d 1046, 1056 (10th Cir. 1994).

6 United States $v$. Pedraza, 27 F.3d 1515, 1530 (10th

Cir.), cert. denied, 115 S. Ct. 347 (1994).

734 F.3d at 932.

${ }^{8}$ U.S.S.G. $§ 3 \mathrm{~B} 1.1$ (a) \& (b) (also allowing increase if activity is otherwise extensive).

9 United States v. Belletiere, 971 F.2d 961, $969-70$ (3d

Cir. 1992); United States $v$. Manthei, 913 F.2d 1130, 1135-36

(5th Cir. 1990).

10 Allemand, 34 F.3d at 931.

11 §3B1.2.

12 United States v. Santistevan, 39 F.3d 250, 254 (10th Cir. 1994).
${ }^{13}$ Id. at 253.

14 See United States v. Ziegler, 39 F.3d 1058 (10th Cir. 1994); United States v. Chubbuck, 32 F.3d 1458 (10th Cir. 1994).

15 United States v. Ziegler, 1 F.3d 1044 (10th Cir. 1993); see also Angela D. Gupta, The Tenth Circuit: A Narrow View of Departures, and Ways to Determine Drug Quantity, 6 Fed.

Sent. R. 269, 270 (1994) (discussing Ziegler I).

1639 F.3d 1058 (10th Cir. 1994).

17 Ziegler II, 39 F.3d at 1061.

18 United States $v$. Fetherolf, 21 F.3d 998, 1000 (10th Cir. 1994) (applying clearly erroneous standard of review).

19 United States v. Rowlett, 23 F.3d 300 (10th Cir. 1994); United States v. Yost, 24 F.3d 99 (10th Cir. 1994); United States $v$. Arias-Santos, 39 F.3d 1070 (10th Cir. 1994), cert. denied, 115 S. Ct. 1156 (1995)

20 United States v. Markum, 4 F.3d 891, 897 (10th Cir. 1993) (citations omitted).

21 United States v. Dunnigan, 113 S. Ct. 1111, 1115-16 (1993); Markum, 4 F.3d at 897-98.

${ }^{22}$ See, e.g., Yost, 24 F.3d at 106. 